\title{
THE EFFECTIVENESS OF COOPERATIVE LEARNING MODEL TYPE OF NHT (NUMBERED HEADS TOGETHER) OF STUDENT AT SMP MUHAMMADIYAH 2 KALASAN
}

\author{
Dian Sulistya Ningruma ${ }^{a}$ Edi Prajitno ${ }^{b}$ \\ Program Studi Pendidikan Matematika Universitas Ahmad Dahlan \\ Jalan Ring Road Selatan, Tamanan, Banguntapan, Bantul Yogyakarta

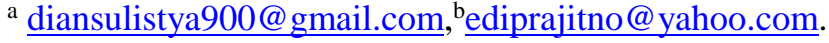

\begin{abstract}
This research was done because the results of students' mathematics learning are still relatively low. Students are reluctant to ask about the material they have not understood that the learning outcomes obtained less optimal. This research aims to determine the results of learning mathematics using of cooperative learning model type of NHT (Numbered Heads Together) of student grade VIII at SMP Muhammadiyah 2 Kalasan Sleman Regency of Even Semester in Academic Year of 2015/2016. This was design is Posttest-Only Control Design. The population in this research were students class VIII SMP Muhammadiyah 2 Kalasan Sleman Regency. Samples of this research using random sampling techniques derived from class VIII A as an experimental class and VIII C as the control class. The data collection is done with the test method. A testing instrument using a validity test and reliability test. Data were analyzed before using hypothesis testing with a t-test first using analysis prerequisite test including normality test, and homogeneity test. Based on calculations by the significant level $\alpha=5 \%$ and the degrees of freedom 65, we concluded that: (1) There are differences in learning outcomes of students learning math using cooperative learning model type of NHT with learning using conventional learning model. This is indicated by the results of the first test of the hypothesis that $t_{c a l}=2,1899$ and $t_{\text {table }}=$ 1,997, so that $t_{\text {cal }}>t_{\text {table }}$. (2) The type of cooperative learning model NHT more effective than the conventional learning model. It is shown on the second hypothesis that the test results $t_{c a l}=2,1899$ and $t_{\text {table }}=1,669$, so $t_{\text {cal }}>t_{\text {table }}$.
\end{abstract}

Keywords: Effectiveness, Mathematics Learning Outcomes, Cooperative Learning Model Type of NHT.

\section{INTRODUCTION}

Education is an important tool for the advancement and intelligence of the next generation. In this case, the school is an educational institution that plays an important role in developing personality and as a foundation for students, so that it can grow and develop according to the national education goals stated in the Law of the Republic of Indonesia No. 20 of 2003 concerning National Education System (National Education System) Chapter I article 1, namely: Education is a conscious and planned effort to create a learning atmosphere and learning process so that students actively develop their potential to have religious-spiritual strength, self-control, personality, intelligence, noble character, and the skills needed by him, society, nation, and country. School education covers a variety of subjects, one of which is mathematics. Mathematics subjects are subjects taught at each level of education, ranging from basic education to tertiary education. Students are expected to learn mathematics so they can think logically, analytically, critically and creatively. Besides that, by studying mathematics it is expected that students can solve problems faced by both problems related to mathematics and problems in everyday life. However, there are still many students who think that mathematics is a difficult and boring subject. To optimize learning goals, one of them can be used as a learning model in the learning process. According to Suprijono, Agus (2012: 46) the learning model is a pattern used as a guide in planning classroom learning and tutorials. According to Arends, the learning model refers to the approach that will be used, including the learning objectives, the stages in learning activities, the learning environment, and classroom management. Learning models can be defined as conceptual frameworks that describe systematic procedures in organizing learning experiences to achieve learning goals. According to Suherman, Erman, et al (2003: 7) the learning model is intended as a pattern of interaction between 
students and teachers in the classroom regarding strategies, approaches, methods, and learning techniques applied in the implementation of teaching and learning activities in the classroom.

Based on the observations of class VIII on November 9, 2015, at SMP Muhammadiyah 2 Kalasan that there were still many students who were less active in participating in the lessons, so there were still many students who had difficulty learning mathematics. Students are not used to looking for other ways that might be able to solve problems in mathematics effectively. This causes students to be less active in communicating with the teacher and their friends, even often students do not pay attention to the material being taught. From the results of interviews with grade VIII mathematics subject teachers on November 9, 2015, the researchers did at SMP Muhammadiyah 2 Kalasan that mathematics learning outcomes were still relatively low. Also, there are still many students who have difficulty understanding the subject matter given by the teacher, even there are still many students who have difficulty completing the practice questions given by the teacher. The indicator of the low mathematics learning outcomes can be seen in the average midterm exam scores for the 2015/2016 academic year. These results can be seen in Table 1 .

Table 1. Even Semester Middle Examination Results of Class VIII Mathematics Subjects of

SMP Muhammadiyah 2 Kalasan Academic Year 2015/2016

\begin{tabular}{|c|c|c|c|c|c|c|c|}
\hline \multirow{2}{*}{ Value } & \multicolumn{5}{|c|}{ Class VII } & \multirow{6}{*}{ Total } & \multirow{6}{*}{$\begin{array}{c}\text { Percentage } \\
(\%)\end{array}$} \\
\hline & $\mathbf{A}$ & B & $\mathbf{C}$ & D & $\mathbf{E}$ & & \\
\hline KKM & 75 & 75 & 75 & 75 & 75 & & \\
\hline Average & 45,97 & 50,44 & 40,5 & 52,37 & 54,31 & & \\
\hline Highest & 83 & 75 & 58 & 80 & 78 & & \\
\hline Lowest & 20 & 28 & 23 & 30 & 20 & & \\
\hline$\geq \mathrm{KKM}$ & 1 & 1 & - & 2 & 2 & 6 & $3,49 \%$ \\
\hline$\leq \mathrm{KKM}$ & 32 & 33 & 34 & 33 & 34 & 166 & $96,51 \%$ \\
\hline
\end{tabular}

(Source: SMP Muhammadiyah 2 Kalasan)

From Table 1, it can be seen that there are still many math UTS scores of students who have not yet reached the KKM (Minimum Completion Criteria) set by the school, which is 75. The percentage of the incompleteness of students' UTS math scores is still $96.51 \%$, while the completeness percentage is only $3.49 \%$. It can be concluded that the learning outcomes of mathematics at Muhammadiyah 2 Middle School in Kalasan are still relatively low. The low student learning outcomes must be corrected immediately so that it is as expected. One of the factors that cause low learning outcomes is because teachers are not precise in choosing a learning model.

The learning model used by the teacher has not prioritized the creativity and activeness of students in mathematics learning because mathematics learning still tends to be teacher-centered. The teacher still uses conventional learning because it is easy to organize the class, it is easy to prepare and implement it. The learning model does not encourage students' creativity and activity in processing learning material and students tend to be passive. Teachers should choose a learning model that can attract the attention of students to be more active in learning, especially mathematics. Mathematics lessons should be sought to be interesting, interactive and fun lessons for students. Learning models that can be used are cooperative. According to Suprijono, Agus (2012: 54-55) Cooperative learning is a broader concept covering all types of group work including forms that are more led by the teacher or directed by the teacher. In general, cooperative learning is considered more directed by the teacher, where the teacher determines the tasks and questions and provides materials and information designed to help students solve the problem in question. The teacher usually sets the form of a particular test at the end of the assignment. Learning can be done by dividing students into small groups to carry out activities together. The cooperative learning model also requires student collaboration and interdependence in the structure of tasks and goals. Several types of cooperative learning models can be used by teachers, one of which is the NHT type. The NHT cooperative learning model is a group discussion that emphasizes student interaction in a group. This type of learning emphasizes collaboration between students in a group so students can be responsible for achieving learning goals. This learning model has 4 steps, namely numbering, asking questions, thinking together and answering. If the NHT type learning model is applied in the learning process, it is expected 
to provide better learning outcomes than before. Besides, it is expected to be able to make students more active and creative.

Based on the background, the identification of the problem and the limitation of the problem described can be formulated as follows:

1. Is there a difference in mathematics learning outcomes between students using the NHT type cooperative learning model and students using conventional learning models in class VIII SMP Muhammadiyah 2 Kalasan Sleman Regency even semester 2015/2016?

2. Is the NHT type of cooperative learning model more effective than the conventional learning model in mathematics learning for class VIII SMP Muhammadiyah 2 Kalasan Sleman Regency even semester 2015/2016?

Based on the formulation of the problem above, this study aims to find out the following things.

1. To find out whether there are differences in mathematics learning outcomes between students using the NHT type cooperative learning model and students using conventional learning models in class VIII SMP Muhammadiyah 2 Kalasan Sleman Regency even semester 2015/2016 academic year.

2. To find out more effective learning between cooperative learning type NHT models compared to conventional learning models in mathematics learning of class VIII SMP Muhammadiyah 2 Kalasan Sleman Regency even semester 2015/2016 academic year.

\section{METHODS}

This type of research is experimental research. Experimental research is a study conducted by learning something held. In other words, in the experimental research, there was the treatment from the researcher and measured the impact (Suparman, 2015: 1). This research was carried out intentionally by the teacher in the classroom or in the school to try the emergence of the variables studied in mathematics learning.

The research design in this study used a posttest-only control design with two treatments, namely the experimental class and the control class. In the experimental class, learning is done using the NHT type learning model, while the control class uses a conventional learning model. In this study, the posttest was done the same, both for the experimental class and for the control class. The design of this study is illustrated in Table 2.

Table 2. Design of the Posttest-Only Control Design study

\begin{tabular}{|l|c|c|c|}
\hline & Group & Treatment & Posttest \\
\hline $\mathrm{R}$ & $\mathrm{A}$ & $\mathrm{X}$ & $\mathrm{O}_{2}$ \\
\hline $\mathrm{R}$ & $\mathrm{B}$ & - & $\mathrm{O}_{4}$ \\
\hline
\end{tabular}

(Sugiyono, 2015:76)

Information :

$\mathrm{R}$ : random

A: experimental group

$\mathrm{B}$ : control group

$\mathrm{X}$ : treatment using the NHT type cooperative learning model

$\mathrm{O}_{2}$ : results of the learning outcomes test using the NHT type cooperative learning model

$\mathrm{O}_{4}$ : results of learning outcomes tests using conventional learning models

This research was conducted at Muhammadiyah 2 Middle School in Kalasan, Sleman Regency. The time of the study was carried out in the even semester of the 2015/2016 academic year on the subject of the pyramid. All eighth-grade students of Muhammadiyah Middle School 2 Kalasan Sleman Regency 2015/2016 Academic Year totaling 172 students. The study sample was carried out by random sampling of the class by lottery method to determine which class will be given NHT type cooperative learning and conventional learning models. The researcher took samples of class VIII A with 33 students as the experimental class, class VIII C with 34 students as controls.

Data collection techniques used are documentation methods and test methods. The documentation used is in the form of the results of observation activities of mathematics learning activities 
of class VIII students of Muhammadiyah 2 Middle School Kalasan to find out the conditions during learning. While the test in the form of a learning outcome test (posttest) was given after receiving treatment with the NHT type cooperative learning model. The instrument used was a test of the learning outcomes of the Limas subject in the form of mathematics learning outcomes test questions. Before being tested in the experimental class, so that the learning outcome test questions are arranged not to deviate from the material to be taught, then a grid is made, test questions, and review the items of the test results of mathematics learning. After the test instruments were arranged, then tested on the instrument trial class, namely class VIII E. After the test questions were tested, the test items were analyzed by validity test using the product-moment correlation formula, the discriminating power using the discrimination index formula, and the reliability test using the formula Kuder Richardson-20 (KR-20). The analysis prerequisite test used the normal test with the Chi-Square test and the homogeneity test with the Bartlet test. Hypothesis testing is used by both parties and one part.

\section{RESULTS AND DISCUSSION}

Based on the research that has been carried out obtained data in the form of initial abilities and student mathematics learning outcomes.

\section{Early Ability}

The initial ability value was obtained from the Even Semester Middle Test grades VIII A and VIII C SMP Muhammadiyah 2 Kalasan Sleman Regency and obtained the value of the initial mathematical abilities as produced in Table 3.

Table 3. Summary of Description of Initial Capability Values

\begin{tabular}{|l|c|c|}
\hline \multicolumn{1}{|c|}{ Parameter } & $\begin{array}{c}\text { Experiment } \\
\text { Class }\end{array}$ & Class Control \\
\hline $\begin{array}{l}\text { The number of } \\
\text { students }\end{array}$ & 33 & 34 \\
\hline The highest score & 83 & 58 \\
\hline Lowest value & 20 & 23 \\
\hline Average & 45,97 & 40,5 \\
\hline Standard Deviation & 15,4565618 & 11,3917833 \\
\hline Variance & 238,905303 & 129,772727 \\
\hline
\end{tabular}

a. Preliminary Ability Value Normality Test Results

The normality test aims to determine whether the ability of the initial experimental class and the control class is normally distributed or not. A summary of the results of the initial capability normality test is presented in Table 4.

Table 4. Summary of Initial Capability Test Results

\begin{tabular}{|c|c|c|}
\hline Class & $\chi_{\text {cal }}^{2}$ & $\chi_{\text {table }}^{2}$ \\
\hline Experiment & 6,617 & 9,488 \\
\hline Control & 4,338 & 5,991 \\
\hline
\end{tabular}

Based on the calculation of the normality test Table 4 experimental class data with a significant level of $5 \%$ and $\mathrm{df}=4$, it can be seen that $\chi_{\text {cal }}^{2}<\chi_{\text {table }}^{2}$ which means that the experimental class has data that is normally distributed. The normality test performed on the control class with a significant level of $5 \%$ and $\mathrm{df}=2$, it can be seen that which means that the experimental class has data that is normally distributed. The normality test performed on the control class with a significant level of $5 \%$ and $\mathrm{df}=2$, it can be seen that $\chi_{\text {cal }}^{2}<\chi_{\text {table }}^{2}$ which means that the control class has data that is normally distributed.

\section{b. Initial Capability Homogeneity Test Results}

Homogeneity tests are conducted to investigate whether the two samples have the same or homogeneous variance. The test used to test the similarity of sample variance is the Bartlett test. 
The process of calculating the homogeneity test is done using the Microsoft Excel program. The data used to perform this test are data from the results of the initial mathematical abilities of students of class VIII A and class VIII C can be seen in Table 5.

Table 5. Summary of Initial Ability Value Homogeneity Test Results

\begin{tabular}{|c|c|}
\hline$\chi_{\text {cal }}^{2}$ & $\chi_{\text {table }}^{2}$ \\
\hline 2,98874 & 3,841 \\
\hline
\end{tabular}

The testing criteria for homogeneity test are if $\chi_{\text {cal }}^{2}<\chi_{\text {table }}^{2}$, then the variance of the sample is homogeneous. Based on Table 5 above, it can be seen that value $\chi_{\text {cal }}^{2}=2,98874$ and $\chi_{\text {table }}^{2}=$ 3,841 , then $\chi_{\text {cal }}^{2}<\chi_{\text {table }}^{2}$ at a significant level of $\alpha=5 \%$ and $\mathrm{df}=1$, so that the variance of the data of students' initial abilities in the study is homogeneous.

c. Hypothesis Test Results of Two Parties Early Capabilities

Summary of the results of the two-part hypothesis test the initial ability of the experimental class and control class can be seen in Table 6 .

Table 6. Summary of Two-part Hypothesis Test Results Initial Capability Value

\begin{tabular}{|c|c|}
\hline $\boldsymbol{t}_{\text {cal }}$ & $\boldsymbol{t}_{\text {table }}$ \\
\hline 1,65236 & 1,997 \\
\hline
\end{tabular}

Based on Table 6 the values obtained $t_{c a l}<t_{\text {table }}$, then $\mathrm{H}_{0}$ is accepted which means that there is no difference in the value of the initial ability of students of class VIII A and VIII C Muhammadiyah Middle School 2 Kalasan Sleman Regency 2015/2016 academic year.

\section{Mathematics Learning Outcomes}

Descriptions of data on student mathematics learning outcomes after the experiment are presented in Table 7.

Table 7. Summary of Description of Value of Mathematics Learning Outcomes

\begin{tabular}{|l|c|c|}
\hline \multicolumn{1}{|c|}{ Parameter } & Experiment Class & Control Class \\
\hline The number of students & 33 & 34 \\
\hline The highest score & 86,7 & 80,0 \\
\hline Lowest value & 33,3 & 33,3 \\
\hline Average & 63,24 & 55,88 \\
\hline Standard Deviation & 14,15194 & 13,3341 \\
\hline Variance & 200,2774 & 177,798 \\
\hline
\end{tabular}

a. Normality Test Results Value of Mathematics Learning Outcomes

The normality test aims to determine whether the value of mathematics learning outcomes of the experimental class students and the control class is normally distributed or not. The summary of the results of the normality test of students' mathematics learning outcomes is presented in Table 8.

Table 8. Summary of Normality Test Results for Mathematics Learning Outcomes

\begin{tabular}{|c|c|c|}
\hline Class & $\chi_{\text {cal }}^{2}$ & $\chi_{\text {table }}^{2}$ \\
\hline Experiment & 3,412 & 9,488 \\
\hline Control & 6,079 & 9,488 \\
\hline
\end{tabular}

Based on the calculation of the normality test Table 8 experimental class data with a significant level of $5 \%$ and $\mathrm{df}=4$, it can be seen that $\chi_{\text {cal }}^{2}<\chi_{\text {table }}^{2}$ which means that the experimental class has data that is normally distributed. The normality test performed on the control class with a significant level of $5 \%$ and $\mathrm{df}=4$, it can be seen that $\chi_{\text {cal }}^{2}<\chi_{\text {table }}^{2}$ which means that the control class has normally distributed data. 


\section{b. Homogeneity Test Results Value of Mathematics Learning Outcomes}

Homogeneity tests are conducted to investigate whether the two samples have the same or homogeneous variance. The test used to test the similarity of the sample variance is the Bartlett test. The process of calculating the homogeneity test is done using the Microsoft Excel program. The data used to perform this test are data from the value of mathematics learning outcomes of students of class VIII A and class VIII C can be seen in Table 9.

Table 9. Summary of Homogeneity Test Results for Mathematics Learning Outcomes

\begin{tabular}{|c|c|}
\hline$\chi_{\text {cal }}^{2}$ & $\chi_{\text {table }}^{2}$ \\
\hline 0,11514 & 3,841 \\
\hline
\end{tabular}

The testing criteria for homogeneity test are if $\chi_{c a l}^{2}<\chi_{\text {table }}^{2}$, then the variance of the sample is homogeneous. Based on Table 9 above it can be seen that the value $\chi_{\text {cal }}^{2}=0,11514$ and $\chi_{\text {table }}^{2}=$ 3,841 , then $\chi_{\text {cal }}^{2}<\chi_{\text {table }}^{2}$ at a significant level of $\alpha=5 \%$ and $\mathrm{df}=1$, so the variance of data on students' mathematics learning outcomes in the study is homogeneous.

c. Test the Two Parties Hypothesis of Mathematics Learning Outcomes

$\mathrm{H}_{0}: \mu_{1}=\mu_{2}$

$\mathrm{H}_{1}: \mu_{1} \neq \mu_{2}$

With

$\mathrm{H}_{0}$ : There was no difference in mathematics learning outcomes between students using the NHT type of cooperative learning model and students using conventional learning models in class VIII SMP Muhammadiyah 2 Kalasan Sleman Regency even semester 2015/2016 academic year.

$\mathrm{H}_{1}$ : There was a difference in mathematics learning outcomes between students using the NHT type of cooperative learning model and students using conventional learning models in class VIII SMP Muhammadiyah 2 Kalasan Sleman Regency even semester 2015/2016 academic year.

Summary of the results of the two-part hypothesis test of mathematics learning outcomes can be seen in Table 10.

Table 10. Summary of Hypothesis Test Results of Two Parties Value of Mathematics Learning Outcomes

\begin{tabular}{|c|c|}
\hline $\boldsymbol{t}_{\text {cal }}$ & $\boldsymbol{t}_{\text {table }}$ \\
\hline 2,1899 & 1,997 \\
\hline
\end{tabular}

Based on Table 10 the values obtained $t_{c a l}>t_{\text {table }}$, then $\mathrm{H} 0$ is rejected which means that there are differences in mathematics learning outcomes between students who use the NHT type cooperative learning model and students who use conventional learning models in class VIII Muhammadiyah Middle School 2 Kalasan Sleman Regency even semester 2015/2016 academic year.

d. Test the One-Part Hypothesis of Mathematics Learning Outcomes

$\mathrm{H}_{0}: \mu_{1}=\mu_{2}$

$\mathrm{H}_{1}: \mu_{1}>\mu_{2}$

With :

$\mathrm{H}_{0}$ : Mathematics learning outcomes of students who use the NHT type cooperative learning model is no more effective than the mathematics learning outcomes of students who use conventional learning models in class VIII SMP Muhammadiyah 2 Kalasan Sleman Regency even semester 2015/2016 academic year.

$\mathrm{H}_{1}$ : The NHT type of cooperative learning model is more effective than the conventional learning model in mathematics learning for eighth-grade students of SMP Muhammadiyah 2 Kalasan Sleman Regency even semester 2015/2016 academic year. 
A summary of the results of the one-part hypothesis test of mathematics learning outcomes can be seen in Table 11 .

Tabel 11. Summary of One-Party Hypothesis Test Results

\begin{tabular}{|c|c|}
\hline $\boldsymbol{t}_{\text {cal }}$ & $\boldsymbol{t}_{\text {table }}$ \\
\hline 2,1899 & 1,669 \\
\hline
\end{tabular}

Based on Table 11 the values obtained $t_{c a l}>t_{\text {table }}$, then $\mathrm{H}_{0}$ is rejected, which means that the NHT type of cooperative learning model is more effective than the conventional learning model in mathematics learning of class VIII SMP Muhammadiyah 2 Kalasan Sleman Regency even semester 2015/2016 academic year.

\section{CONCLUSION}

Based on the results of the research and discussion above, some research conclusions can be drawn as follows:

1. There are differences in mathematics learning outcomes between students who use the NHT type cooperative learning model and students who use conventional learning models in class VIII SMP Muhammadiyah 2 Kalasan Sleman District 2015/2016 academic year. This is indicated by the hypothesis of two parties with a significant level of $5 \%$ and 65 degrees of freedom, then the value of $t_{\text {cal }}=2.1899$ and $t_{\text {table }}=1.997$, so that $t_{\text {cal }}>t_{\text {table }} \mathrm{H}_{0}$ is rejected and $\mathrm{H}_{1}$ is accepted.

2. The NHT type of cooperative learning model is more effective than the conventional learning model in mathematics learning for eighth-grade students of SMP Muhammadiyah 2 Kalasan Sleman Regency even semester 2015/2016 academic year. These results are indicated by the results of a onepart hypothesis test with a significant level of $5 \%$ and 65 degrees of freedom, then $t_{c a l}=2.1899$ and $t_{\text {table }}=1.669$, so $t_{\text {cal }}>t_{\text {table }} \mathrm{H}_{0}$ is rejected and $\mathrm{H}_{1}$ is accepted.

\section{REFERENCES}

Sugiyono. 2015. Metode Penelitian Kuantitatif, Kualitatif, dan R\&D. Bandung: Alfabeta.

Suherman, Erman, dkk. 2003. Strategi Pembelajaran Matematika Kontemporer. Yogyakarta: Universitas Pendidikan Indonesia.

Sudjana. 2005. Metode Statistik. Bandung: PT Tarsito.

Suparman. 2015. Metodologi Penelitian Pendidikan. Yogyakarta: MIPA UAD Press.

Suprijono, Agus. 2012. Cooperative Learning. Yogyakarta: Pustaka Pelajar.

Undang-undang Republik Indonesia No 20 Tahun 2003 Bab 1 Pasal 1 Sistem Pendidikan Nasional. 